\title{
LAISVALAIKIO IR DARBO KOKYBINĖS INDIKACIJOS VERTINIMAS
}

\section{Viktorija Kanapinskaitè}

\author{
Lietuvos sporto universitetas, Kaunas, Lietuva
}

\begin{abstract}
ANOTACIJA
Straipsnyje pristatoma laisvalaikio ir darbo kokybinès indikacijos, kurios yra vertinamos laisvalaikio ir darbo tarpusavio ryšiais. Kokybinès indikacijos yra labai svarbios, nes nuo jų priklauso gyvenimo ir darbo kokybè. Tyrimas atskleide, kokios indikacijos lemia laisvalaikio ir darbo tarpusavio ryšsi, kurios indikacijos vertinamos labiausiai, kurios mažiausiai.
\end{abstract}

Raktažodžiai: laisvalaikis, darbas, kokybinès indikacijos.

\section{IVADAS}

Vertindami šiuolaikinę aplinką, kurioje gyvename, pastebime, kad visi nuolat skubame, lekiame ir stebime, kaip kuriamos naujausios technologijos, stengiamès prie jų kuo greičiau prisitaikyti, daug dirbame ir dažnai pamirštame kitus savo poreikius. Laisvalaikis yra viena iš svarbiausių žmogaus egzistavimo sąlygų, kuri yra įtvirtinta Lietuvos Konstitucinèje teisèje. Joje nurodoma, kad kiekvienas žmogus turi teisę ị poilsị ir laisvalaikį. Anot G. Gerikaitès ir kt. (2014), norint spręsti laisvalaikio kokybės socialinėje sistemoje problemas, šiandien ypač stokojama žinių ir tyrimų. Nuolat vykstant esminiams pokyčiams visuomenèje, vis labiau jaučiamas laisvalaikio paslaugu poreikis, tačiau ne visuomet gyventojai gali ji patenkinti. Didžiuosiuose miestuose ar specialiai ị laisvalaikị orientuotuose šalies rajonuose sporto ar rekreacinių paslaugų spektras yra itin gausus ir gyventojų poreikiai pilnai patenkinti. L. Kublickienė (2001), kritiškai vertindama laisvalaikio tyrimus, akcentuoja, kad dažniausiai tiriamos vien konkrečios laisvalaikio veiklos, ju pasirinkimo dažnumas ar trukmè. Darbas yra pagrindinė asmens veikla, kurioje jis praleidžia, ko gero, didžiausią savo laiko dalị. Labai panašią laiko dalį žmonès praleidžia net ir miegodami, o ryšiai tarp šių dviejų milžinišką asmens gyvenimo dali apimančių veiklų nėra iki galo atskleisti, todėl tirti juos svarbu. Šiuo tyrimu siekiama ištirti darbo ir laisvalaikio kokybines indikacijas. Mažiau tirta sritis būtų laisvalaikis, nors didžiają žmogaus gyvenimo dalị užima darbas.

Temos aktualumas. Šiuolaikinèje visuomenèje iš esmès kinta darbo ir laisvalaikio sampratos bei su šiomis žmogaus gyvenimo sritimis susijusios vertybès. Darbas yra ne tik pagrindinè gyvenimo sritis, bet ir žmogaus kaip asmenybès formavimosi ir vystymosi sritis. Sociologiniu požiūriu tai yra sąmoninga, universali ir organizuota žmogaus veikla, kurios turinị ir pobūdị lemia darbo priemonių išsivystymo lygis ir visuomeninių santykių ypatumai. Jei jau kalbama apie darbą, neįmanoma nepaliesti laisvalaikio temos. Laisvalaikis, kuris tradiciškai apibrěžiamas kaip laikas, laisvas nuo mokamo darbo, nuo buitinių ir fiziologinių reikmių tenkinimo, yra mažiausiai instituciškai ir socialiai reglamentuota žmogaus gyvenimo sfera. Būtent todèl jis vertinamas kaip ypač svarbi erdvè, suteikianti žmogui galimybę save tobulinti ir realizuoti, turèti individualų pasirinkimą.

Tyrimo tikslas - ịvertinti laisvalaikio ir darbo kokybines indikacijas.

Tyrimo objektas - laisvalaikio ir darbo kokybinès indikacijos. 
Tyrimo problema - kuo laisvalaikis padeda darbo kokybei? Kokie kokybiniai indikatoriai padeda susieti darbą su laisvalaikiu ir kaip laisvalaikis prisideda prie darbo kokybès?

\section{METODIKA}

Žinoma, gyvenime darbas neatsiejamas nuo laisvalaikio, nes dirbant žmogui reikia atgauti fizines ir psichologines jègas. Kai kurių autorių (Parasuraman, Greenhaus, 2002; Cropley, Millward, 2009; Akmal et al., 2012) tyrimai rodo, kad lankstūs darbo grafikai leidžia darbuotojui efektyviau ir laiku išnaudoti laisvą laiką, planuoti įvairias savo veiklos rūšis taip, kad atitiktų darbuotojo lūkesčius. Pasak E. J. Hill'o ir kt. (2003), R. Neuendorf'o ir kt. (2015), C. D. Niklas ir C. Dormann'o (2005), atsipalaidavimas yra susijęs su darbo kokybe. Asmenys, kurie geriau atsipalaiduoja, pailsi, kokybiškiau ir dirba. Darbo krūvis priklauso nuo darbo organizavimo ir daugumai žmonių darbo laiko užtenka tam, kad būtų tinkamai atliktos skiriamos užduotys. Y. Jis'o ir kt. (2014), R. Rapoport ir kt. (2002) teigia, kad organizaciniai pokyčiai dèl globalizacijos, didina darbo krūvị ir psichologini spaudimą dirbti ilgas valandas, siekiant patenkinti darbdavio lūkesčius. Pasak J. N. Luchman'o ir M. G. González-Morales (2013), laisvas laikas gali būti tobulëjimo, naujos patirties, ramybès, džiaugsmo ar net finansų šaltiniu. Kiti autoriai (Primeau, 1996; Aleksandravičius ir kt., 2010; Xanthopoulou et al., 2012; Zacher et al., 2014) teigia, kad visuomenejje galima išskirti tokias gausias vertybinèmis orientacijomis pagrịstas sritis: draugystè, šeima, religija ir moralé, politika ir socialinè organizacija, meilè ir seksas, laisvalaikis, subrendimas, charakterio bruožai ir darbas. Šios indikacijos skatina tinkamai pailsėti, nuotaikingai praleisti laisvalaikį, kartu pagerinti ir pačią darbo kokybę. Laisvalaikio konstruktas - laisvè, atsipalaidavimas, laimè, galimybė pasirinkti. Laisvalaikio programų, užimtumo ne darbo metu kūrimas leidžia sumažinti sveikatos priežiūros išlaidas.

Siekiant atskleisti darbo ir laisvalaikio kokybines indikacijas, buvo atliekamas kiekybinis tyrimas. Kiekybinis tyrimas - tai struktūrizuotas, besiremiantis iš mokslinès problemos kylančia hipoteze tyrimas taikant matematinius analizès metodus tyrimo duomenims apdoroti bei nagrinėjamam reiškiniui aprašyti (Žukauskienè, 2008). Tyrimas buvo atliekamas anketinès apklausos būdu internetu (396) ir keletas anketų užpildyta raštu (12). Iš viso ị anketą atsakè 408 respondentai, bet iš jų liko 396 respondentai, nes buvo tokių respondentų, kurie pradejjo pildyti anketą, bet jos neužbaigè, buvo netinkamai atsakyti klausimai raštu. Klausimai buvo įkelti i tinklalapi apklausa.lt ir

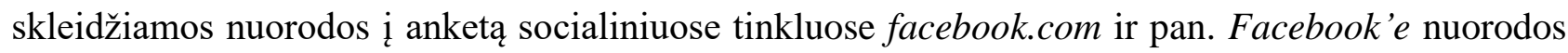
buvo siunčiamos dirbantiems žmonėms asmeniškai ir i grupes: LSU studentai, LSU sportinė rekreacija ir turizmas 2014, LSU trečiakursiai, mamyčių turgelis, darbo birža, Kaišiadorių grupe ir pan. Pagal šiuos klausimus buvo atliekamas tyrimas. Tyrimas analizuotas Microsoft Office Excel programa, nes su šia programa dauguma yra susipažinę ir su ja, patogu dirbti, analizuoti ir aprašyti rezultatus. Tad pagal šią programą gauti tyrimo rezultatai ir pateikti. Tyrimo imtis buvo apskaičiuota pagal Paniott'o formulę. Analizuojant buvo naudojama aprašomoji statistika, ir rezultatai pateikiami konkrečiais skaičiais. Šis tyrimas atliktas 2018 m. vasario-balandžio mėnesiais.

Tyrimo imtis nustatyta remiantis Paniott'o formule (Valackienè, 2004)

$$
n=\frac{1}{\Delta^{2}+\frac{1}{N}},
$$

kur $\mathrm{n}$ - imties dydis, kai imties paklaidos galimybè $\mathrm{p}=0,954$; 
$\mathrm{N}$ - generalinès visumos dydis;

$\Delta$ - leidžiamos paklaidos imties dydis ( 0,05$)$.

\section{TYRIMO REZULTATAI IR APTARIMAS}

Skirstinio pagal lytį rezultatai rodo, kad didžiąą dali tirtų respondentų $(69,7 \% ; n=276)$ sudarè moterys ir 30,\% $(\mathrm{n}=120)$ vyrai.

Didžiausios grupès tiriamųų amžius - 26-35metai $(42,4 \%$; $n=168)$, mažiau buvo 46-55 metų ir vyresnių $(5,8 \% ; \mathrm{n}=23)$.

Kalbant apie respondentų išsilavinimą, beveik pusè visų apklaustųjų (32,6\%) turejjo bakalauro laipsnị (n = 129), kiek mažiau (24\%) respondentų buvo dirbančių ir turinčių aukštesnij̣i išsilavinimą $(n=95)$. Panašus skaičius buvo ir igijusių magistro laipsnị $(22,7 \% ; n=90)$. Tarp šių respondentų buvo ir mokslų daktaro laipsnị igijusių žmonių $(1,2 \% ; n=5)$.

Didžioji dalis apklaustụjų turèjo 5-10 m. darbo stažą $(35,6 \%$; n = 141) ir jų amžius siekè 2635 metus. Tik nedidelè dalis respondentų turèjo didesnị nei 20 metų darbo stažą $(4,8 \% ; n=19)$, nes jie buvo 46-55 metų amžiaus ir vyresni.

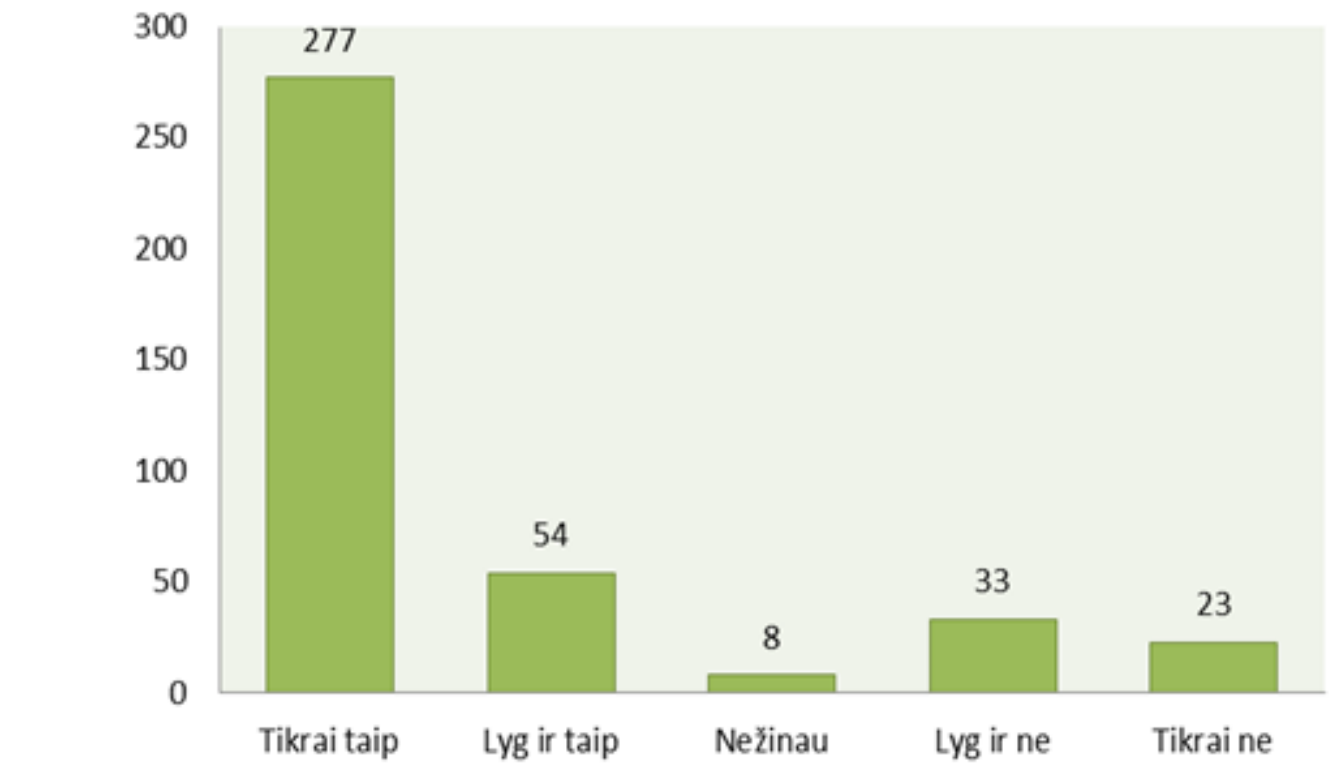

1 pav. Asmeninių gebėjimų tobulinimo darbe pasiskirstymas (darbuotojų skaičius)

Pirmame paveiksle vertinama asmeninių gebejjimų tobulinimas darbe. 277 respondentai savo darbinèje aplinkoje tobulina asmeninius gebejjimus. Tuo tarpu 23 respondentai teigia, kad darbinèje aplinkoje netobulina jų. Didžioji dalis dirbančiųjų visgi savo darbinėje aplinkoje tobulina asmeninius gebejjimus ir yra patenkinti darbine aplinka. 


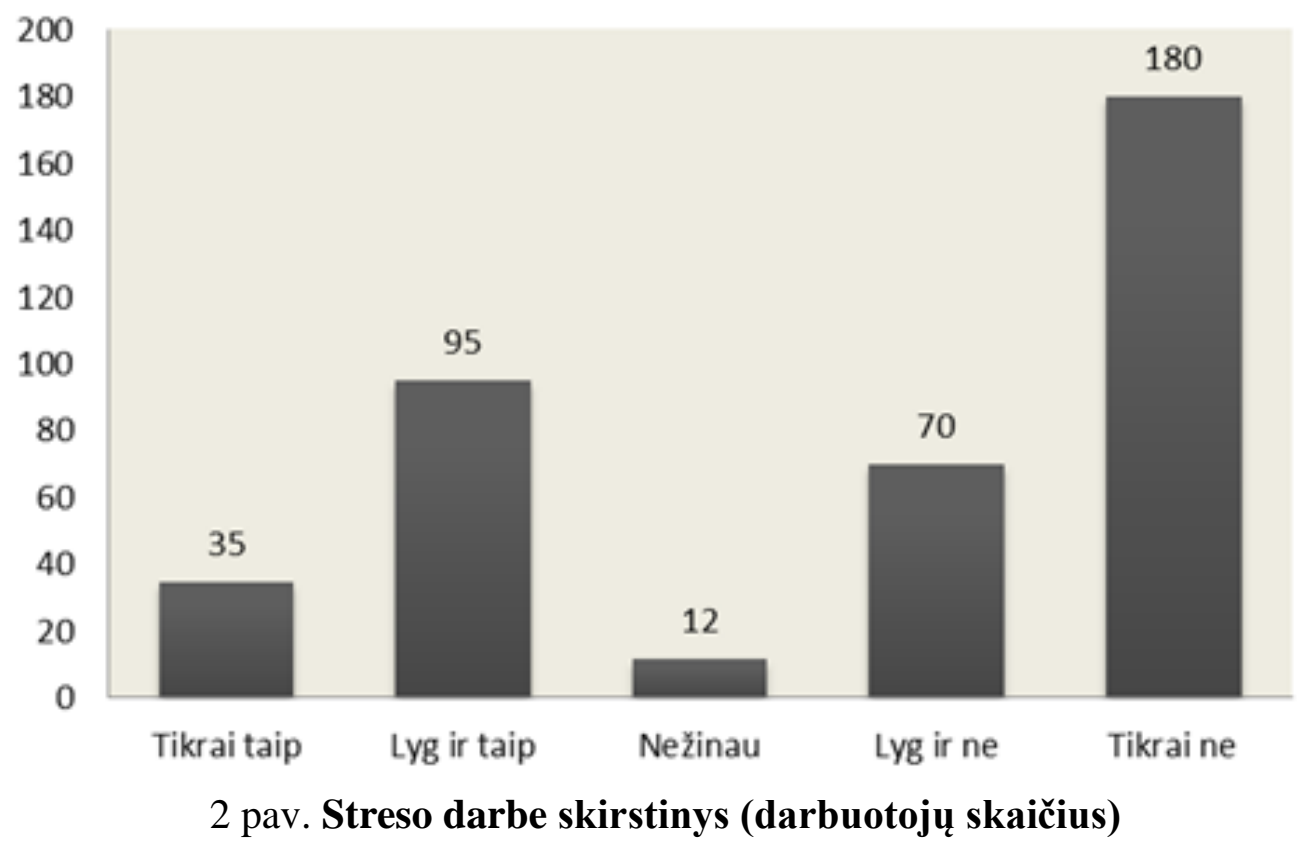

Antrame paveiksle vertinamas stresas darbe. 180 respondentų savo darbo vietoje tikrai nejaučia streso. 95 respondentai jaučia lengvą stresą. 35 respondentai jaučia nuolatinị stresą. Iš paveikslo matyti, kad respondentų atsakymai pasiskirste labai įvairiai, ir stresas yra dažnas darbo vietoje.

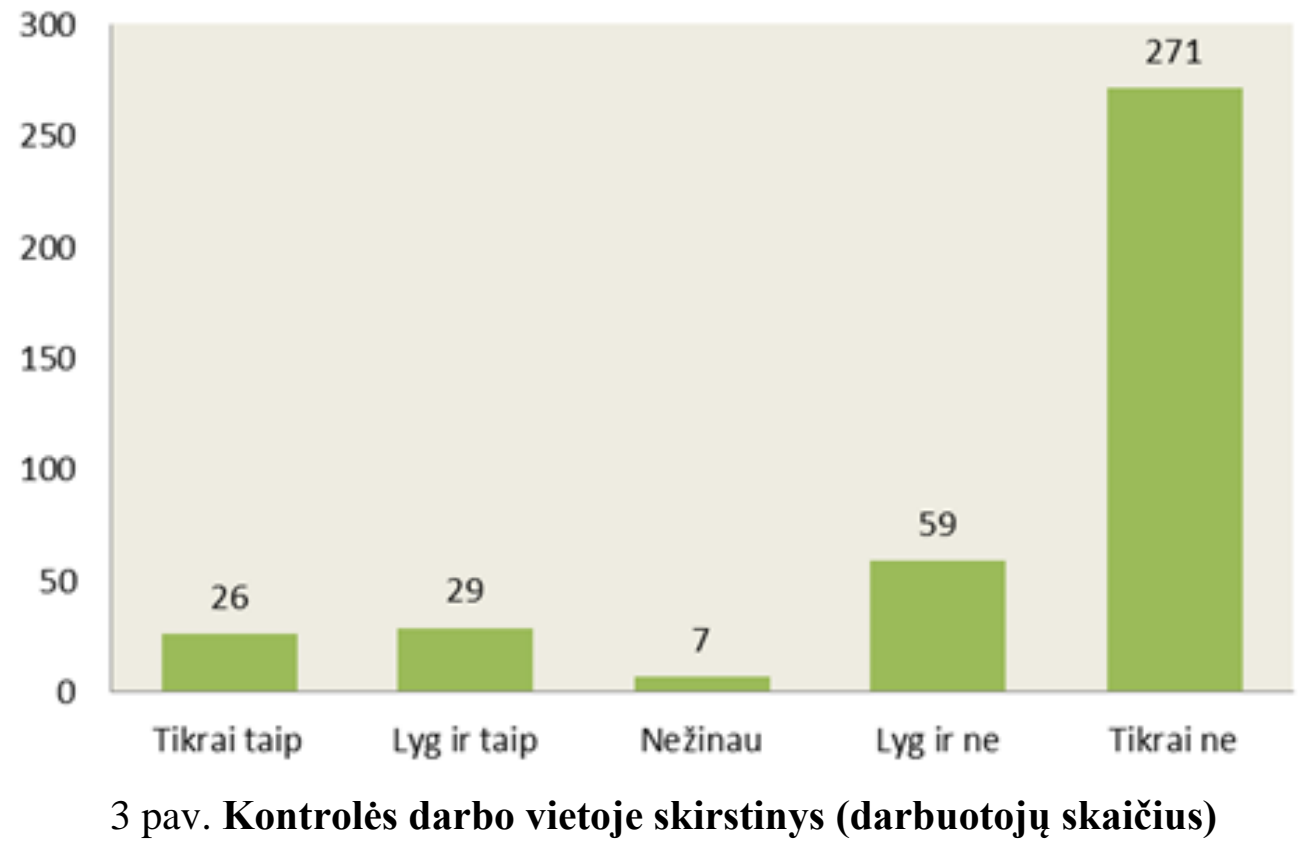

Trečiame paveiksle vertinama kontrolè darbo vietoje. 271 respondentas tikrai nejaučia kontrolès darbo vietoje, o 26 jaučia nuolatinę kontrolę. Vadinasi, didžioji dalis respondentų nesijaučia kontroliuojami darbe. 


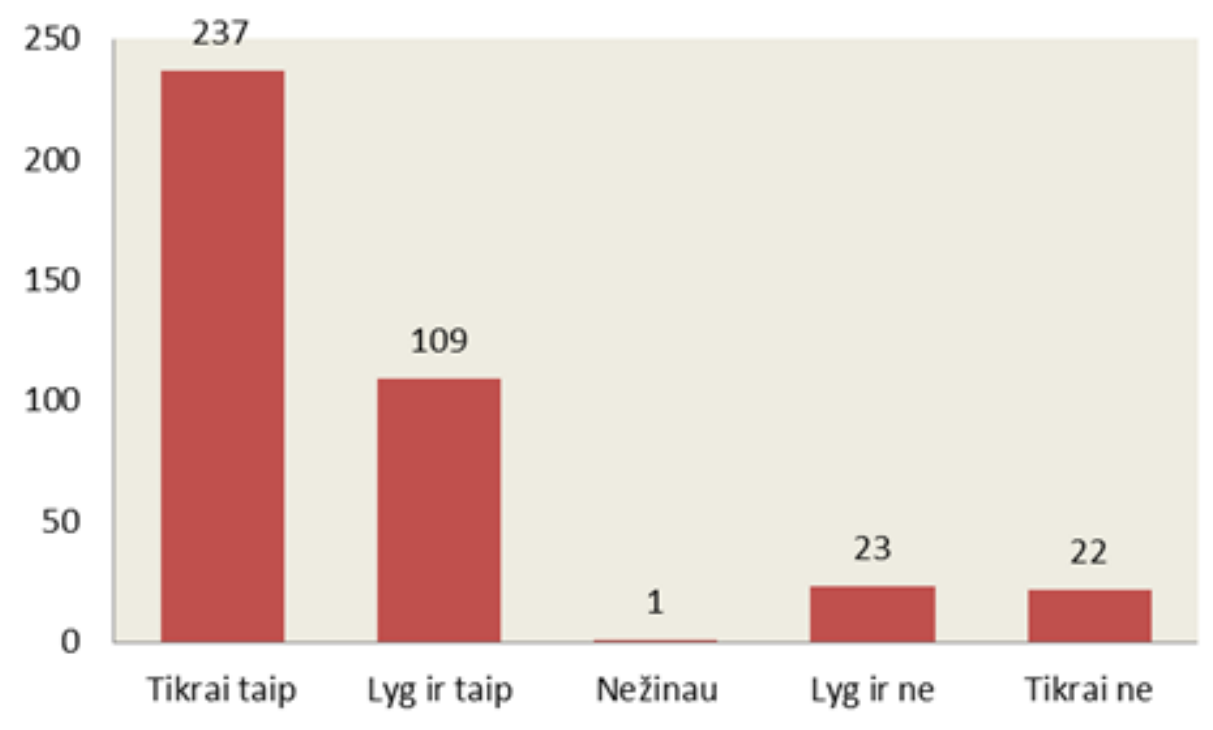

4 pav. Laisvo laiko po darbo skirstinys (darbuotojų skaičius)

Ketvirtame paveiksle vertinamas laisvas laikas po darbo. 237 respondentai po darbo dienos tikrai turi laisvo laiko, o 22 teigia dèl ilgų darbo valandų jo neturintys. Vadinasi, kad didžioji dauguma respondentų po darbo valandų turi laisvo laiko sau.

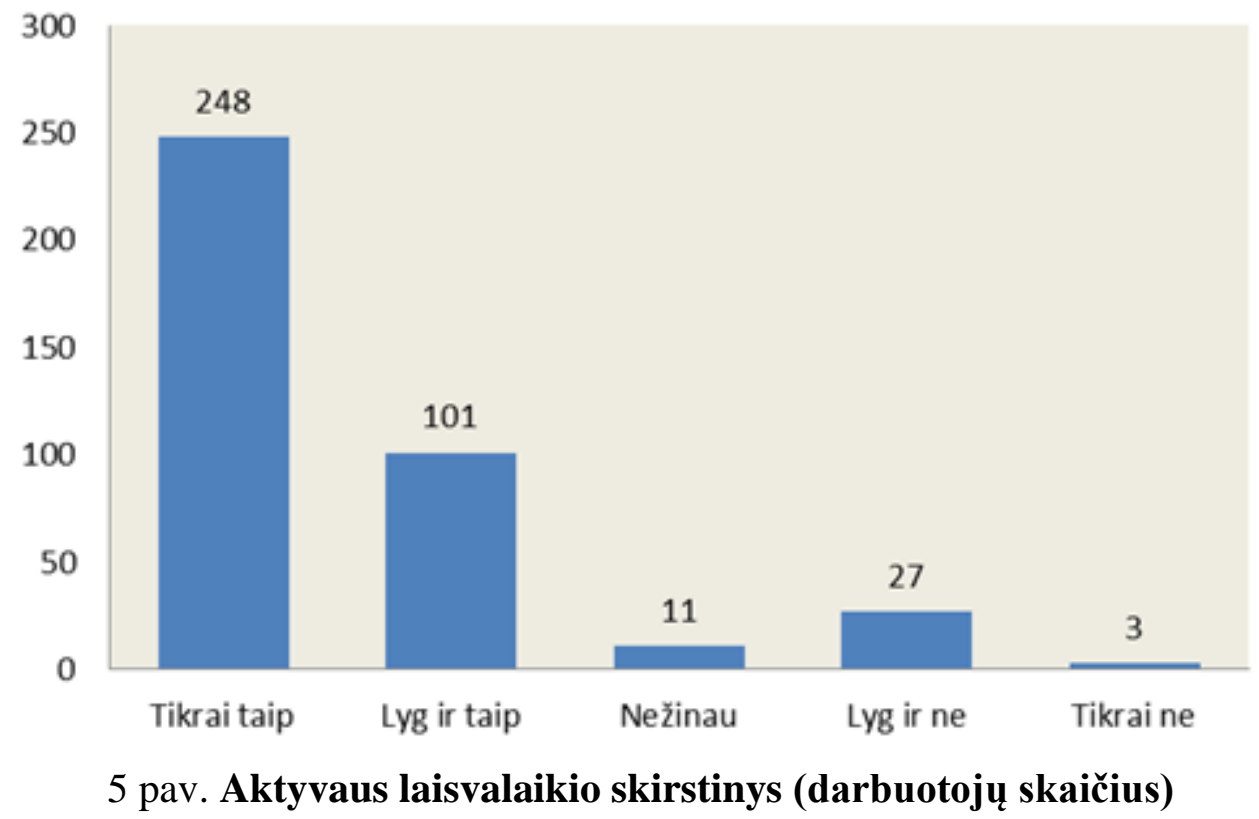

Penktame paveiksle vertinamas aktyvaus laisvalaikio pasirinkimas. 248 respondentai renkasi praleisti laisvalaiki aktyviai, o 3 nesirenka tokio laisvalaikio būdo. Vadinasi, didžioji dauguma respondentų mieliau renkasi aktyvų laisvalaikio būdą. 


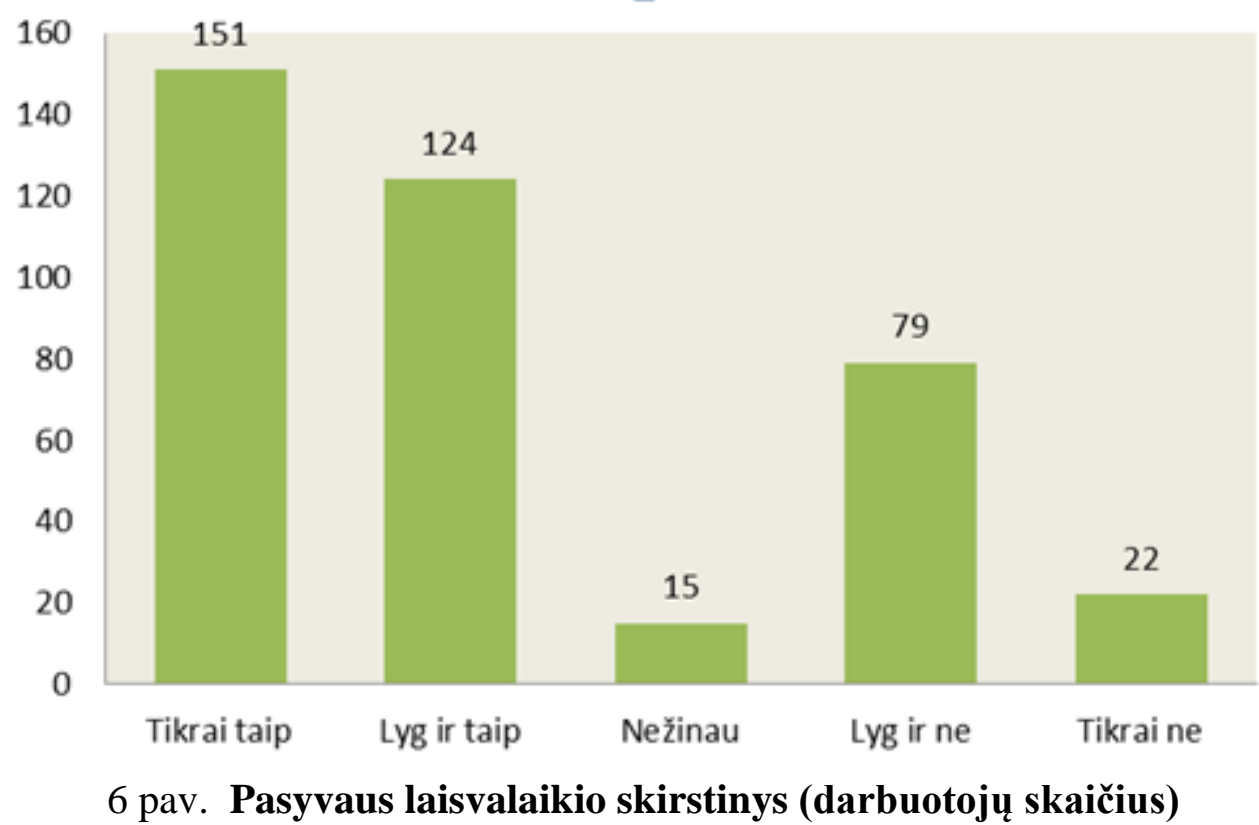

Šeštame paveiksle vertinamas pasyvaus laisvalaikio būdas. 151 respondentas tikrai renkasi pasyvų laisvalaikio būdą, tačiau 22 teigia, kad tokio laisvalaikio tipo nesirenka. Todèl didžioji dauguma noriai praleidžia savo laisvalaikị pasyviai.

Apibendrinus penktą ir šeštą paveikslus matyti, kad respondentai tiesiog neapsisprendžia, kuris laisvalaikio būdas jiems yra priimtinesnis, nes lyg ir didžioji dauguma renkasi aktyvų laisvalaikio būdą (5 pav.), o pasyvus laisvalaikis jiems yra labai priimtinas (6 pav.), ir jie renkasi tokią laisvalaikio formą. Tad galima daryti prielaidą, kad tiriamieji renkasi tiek aktyvaus, tiek pasyvaus laisvalaikio formas.

\section{IŠVADOS IR PERSPEKTYVOS}

Indikatoriai, rodantys laisvalaikio ir darbo kokybės indikacijas, yra šių laikų visuomenès vertybès, kurios skatina žmones elgtis atitinkamai su kitais asmenimis darbo laiku, viešuose renginiuose, pasirinktu laisvalaikiu, internetinejje erdvejje ir kitur. Esminius indikatorius, atskleidžiančius laisvalaikio ir darbo kokybės indikacijas, sudaro darbo charakteristikos, aplinkos ir asmens tapatumo modeliai. Kokybinès indikacijos, lemiančios laisvalaikio ir darbo kokybę, yra šios: asmeninių gebėjimų tobulinimo darbe; fizinès, psichologinès, emocinès pastangos darbe; palaikymas darbo metu, jei padaromos klaidos; darbo lūkesčių tenkinimas darbinèje veikloje; streso ir kontrolès lygis darbe; darbo kokybė po poilsio, atsiradusio laisvo laiko po darbo; aktyvaus ir pasyvaus laisvalaikio ir jo pasirinkimo formos bei laikas; mėgstamos veiklos; galvojimas apie darbą laisvalaikiu; laisvalaikio su šeima ir draugais pobūdis. Aukščiausiai vertinamos šios indikacijos: laisvalaikio praleidimas su šeimos nariais ar draugais; asmeninių gebejjimų tobulinimas darbe; aktyvus bei pasyvus laisvalaikio būdas; mėgstamos veiklos pasirinkimas; laisvo laiko grafiko pasirinkimas ir pan. Žemiausiai vertinamos - stresas ir kontrolè darbinèje aplinkoje; fizinès, psichologinès bei emocinès pastangos darbo metu; galvojimas apie darbą laisvo laiko metu; darbo lūkesčiai ir pan. Norètume pabrèžti, kad būtina surasti darbo ir laisvalaikio pusiausvyrą. Subalansuota 
pusiausvyra gali pasitarnauti kaip prevencinè priemonė vengiant žalingų ịpročių ir mažinant sveikatos priežiūros išlaidas.

Iš apžvelgtos literatūros matyti, kad šiomis dienomis stokojama informacijos apie laisvalaiki ir patarimų, kaip laisvalaiki praleisti kuo įdomiau, kur semtis įdomaus ir produktyvaus laisvo laiko išnaudojimo idejjų. Be to, stokojama informacijos, iš kurios būtų galima sužinoti, kaip darbo metu (laisvą minutę ar kavos pertraukèlès metu) atsipalaiduoti nuo darbo.

Taigi būtina:

1. Apie laisvalaikị ir jo praleidimo būdus skleisti kuo daugiau informacijos internetu.

2. Skatinti darbuotojus tam tikromis išvykomis, kuriose jie galètų atsipalaiduoti ir nors trumpam negalvoti apie darbą ir jo monotoniškumą.

3. Darbo vietoje kabinti plakatus, dalytis informacija apie keliones, laisvalaiki ir pab. taip juos skatinant kup įdomiau leisti laisvalaikị.

\section{LITERATŪRA}

1. Akmal, F., Zainol, F. A., Mansor, M., Ghazali, Z. (2012). Recreational program and its association with job satisfaction. Asian Social Science, 8 (13), 172-180.

2. Aleksandravičius, A., Navasaitienè, S., Vasylienė, E. (2010). Šakių rajono jaunimo pagrindiniu problemu, poreikiu ir vertybiniu nuostatu mokslinis tyrimas. Kaunas: Lietuvos žemės ūkio universitetas. P. 118.

3. Cropley, M., Millward, L. J. (2009). How do individuals 'switch-off' from work during leisure? A qualitative description of the unwinding process in high and low ruminators. Leisure Studies, 28, 333-347.

4. Gerikaite, G., Manukian, D., Vaitiekienè, N. (2014). Laisvalaikio organizavimo specialistu poreikis socialinių paslaugų bei sveikatos priežiūros institucijose. Profesinès studijos: teorija ir praktika, 14, 140147.

5. Hill, E. J., Ferris, M., Martinson, V. (2003). Does it matter where you work? A comparison of how three work venues influence aspects of work and personal/family life. Journal of Vocational Behavior, 62, 220 241.

6. Jia, Y., Gao, J., Dai, J. et al. (2014). Difference of the associations between self-rated health and demographic characteristics, lifestyle, and psychosocial work environment between two types of Chinese worksite. BMC Public Health, 14 (1), 851.

7. Kublickienè, L. (2001). Laisvalaikio sociologija: paradigmų skirtumai. Filosofija. Sociologija, 12 (2), 3542

8. Luchman, J. N., González-Morales, M. G. (2013). Demands, control, and support: A metaanalytic review of work characteristics interrelationships. Journal of Occupational Health Psychology, 18 (1), 37-52.

9. Neuendorf, R., Wahbeh, H., Chamine, I., Yu, J., Hutchison, K., Oken, B. S. (2015). The effects of mindbody interventions on sleep quality: A systematic review. Evidence-Based Complementary and Alternative Medicine, Ecam, 2015902708. doi: 10.1155/2015/902708

10. Niklas, C. D., Dormann, C. (2005). The impact of state effect on job satisfaction. European Journal of Work and Organizational Psychology, 14 (4), 367-388. 
11. Parasuraman, S., Greenhaus, J. H. (2002). Toward reducing some critical gaps in work-family research. Human Resource Management Review, 12, 299-312.

12. Primeau, C. A. (1996). Work and leisure: Transcending the dichotomy. American Journal of Occupational Therapy, 50, 569-577.

13. Rapoport, R. (2002). Beyond Work-family Balance: Advancing Gender Equity and Work Performance. San Francisco, CA: Jossey-Bass.

14. Valackienè, A. (2004). Sociologinis tyrimas. Kaunas: Technologija.

15. Xanthopoulou, D., Bakker, A. B., Demerouti, E., Schaufeli, W. B. (2012). A diary study on the happy worker: How job resources relate to positive emotions and personal resources. European Journal of Work and Organizational Psychology, 21 (4), 489-517.

16. Zacher H., Feldman D. C., Schulz H. (2014). Age, occupational strain and wellbeing: A personenvironment fit perspective. The role of demographics in occupational stress and well-being research in occupational stress and well-being. Research in Occupational Stress and Well-being, 12, 83-111.

17. Žukauskienè, R. (2008). Kokybiniai ir kiekybiniai metodai. Vilnius: Mykolo Romerio universitetas.

\section{EVALUATION OF LEISURE AND LABOUR QUALITY INDICATION}

\section{Viktorija Kanapinskaitė}

Lithuanian Sports University, Kaunas, Lithuania

Objective - Rate the leisure time and work quality indications.

Methods - Questionnaire survey.

Relevance of the research. There are not many investigations related to psychosocial work characteristics and employees' age. The majority of investigations are more focused on work characteristics and other variables, especially health, connections and more concentrating on their age; however they do not tend to focus on work characteristics and connections with demographic measures. Research aim was to reveal the leisure time and work quality indications and the influence of these indications in the relationship between leisure time and work time. There were 396 respondents in this investigation.

Research results and conclusions. Analysis of scientific literature revealed that leisure time was defined and understood as free time from necessary activities. This time is dedicated to accommodate ones needs, also to widen the circle knowledge, develop skills and to improve both physical and spiritual status. Work is an absolutely obligatory part of the person's life which takes a lot of person's time. Essential indicators disclose the leisure time and work quality indications which consist of work characteristics, the environment and person's identity module. The research confirmed that qualitative indications that determine leisure time and work quality are the following: improving personal abilities at work, physical, psychological and emotional efforts at work, given support at work if mistakes are made, work expectation satisfaction in the work activities, stress and regulation levels at work, work quality after leisure time, occurrence of free time after work, active and passive leisure time and its chosen form and time, enjoyable activities, thinking about work while having leisure time, leisure time with friends and family. The most important and highest rated are these indications: spending leisure time with friends or family, improving personal abilities at work, the support at work, productive leisure time, etc., the less important ones are stress, regulation and control while 
working, physical, psychological and emotional effort at work, etc. It is important to emphasize that today it is relevant to discover the balance between work and leisure time as this appropriate balance can be valued as a preventive tool to avoid harmful habits and the reason why essential health care expenses are minimised.

Keywords: leisure, work, quality indication. 